\title{
Evaluation of ammonia emissions from filtration of digestate used for fertigation
}

\author{
Celeste Righi Ricco, Alberto Finzi, Viviana Guido, Elisabetta Riva, Omar Ferrari, Giorgio Provolo \\ Department of Agricultural and Environmental Sciences, University of Milan, Milan, Italy
}

\begin{abstract}
Fertigation can be a suitable technique for utilizing digestate, minimizing nitrogen losses, and contributing to circularity within a farming system. For this purpose, digestate usually is first processed with a screw-press separator. However, further filtration is required to remove particles that could clog the nozzles of drip or sprinkling irrigation systems. Advanced filtration can be obtained using mechanical separation with screens having openings of 100$300 \mu \mathrm{m}$. This operation can be another source of ammonia emission, but this aspect has not been adequately investigated.

This study aimed to address this knowledge gap by evaluating the emissions from three different filtration systems for digestate. The study was conducted in three different farms located in Lombardy (Italy) using digestate to fertigate maize by drip irrigation (two farms) and pivot irrigation (one farm).

Ammonia emissions were measured with passive samplers and the fluxes were examined using an inverse dispersion model implemented in Windtrax software. The emissions were measured both when the filtration systems were in operation and when they were switched off.

Ammonia emissions (mean values between 375 and $876 \mu \mathrm{g}$ $\mathrm{NH}_{3} / \mathrm{m}^{2} / \mathrm{s}$ ) tended to increase during operation of the filtration systems. However, no significant differences were found in the emis-
\end{abstract}

Correspondence: Celeste Righi Ricco, Department of Agricultural and Environmental Sciences, University of Milan, via G. Celoria 2, 20133 Milan, Italy.

E-mail: celesterighiricco@gmail.com

Key words: Ammonia emissions; digestate; passive samplers; solid-liquid separation; Windtrax.

Acknowledgements: this research was funded by the project LIFE16 ENV/ES/000400 ARIMEDA Ammonia emission reduction in Mediterranean agriculture with innovative slurry fertigation techniques. A special thanks to all the farmers that have contributed to make this project possible and that shared our engagement in making agriculture more sustainable.

Received for publication: 20 April 2021.

Accepted for publication: 12 July 2021.

CC Copyright: the Author(s), 2021

Licensee PAGEPress, Italy

Journal of Agricultural Engineering 2021; LII:1187

doi:10.4081/jae.2021.1187

This article is distributed under the terms of the Creative Commons Attribution Noncommercial License (by-nc 4.0) which permits any noncommercial use, distribution, and reproduction in any medium, provided the original author(s) and source are credited. sions from active and inactive equipment on any of the farms. The emissions from the filtration systems were higher than from a storage tank (22-67 $\left.\mu \mathrm{g} \mathrm{NH} / \mathrm{m}^{2} / \mathrm{s}\right)$. However, the mean emissions amounted to only $0.3 \%$ of the nitrogen content of the digestate. These emissions can be considered irrelevant in the context of the whole management scheme for digestate.

This work provides a first insight on ammonia emissions arising from advanced filtration of digestate, with specific reference to Po Valley farming systems. Further studies are required to improve knowledge about emissions from the entire digestate management process, including the treatments required for specific application techniques.

\section{Introduction}

Air pollution significantly affects human health and causes diseases in people all over the world (Wagner et al., 2017). Not only do contaminant emissions affect human health, they also have a negative impact on land and water ecosystems, threatening biodiversity (Aneja et al., 2000; Phillips et al., 2001; Rabaud et al., 2001).

Among some well-known pollutants (such as $\mathrm{CO}_{2}, \mathrm{CH}_{4}$ and $\mathrm{N}_{2} \mathrm{O}$ ), ammonia $\left(\mathrm{NH}_{3}\right)$ is the best known pollutant in agriculture. Ammonia is the main precursor for the formation of secondary inorganic particles in the atmosphere, such as particulate matter. These are considered among the most important atmospheric pollutants because of their potential impact on human health (Hill et al., 2008; Zilio et al., 2020).

The agricultural sector contributes approximately $10 \%$ of total greenhouse gas emissions in Europe (EUROSTAT, 2017), however, it emits up to $90 \%$ of the total $\mathrm{NH}_{3}$ emissions (Ferrara et al., 2016; Pacholski, 2016). Among agricultural activities, intensive livestock farming has been associated with excessive $\mathrm{NH}_{3}$ emissions (Aneja et al., 2000; Ferrara et al., 2016). The major sources of $\mathrm{NH}_{3}$ emissions in a livestock (or crop-mixed-with-livestock) farming system include barns, animal waste storage (such as slurry or digestate lagoons or manure heaps), fertilizer application and soil emissions (Ferrara et al., 2016; Wagner et al., 2017).

After being emitted into the atmosphere, $\mathrm{NH}_{3}$ is dispersed and can then either deposit close to its emitting source or be transported for long distances as ammonium aerosols (Wagner et al., 2017). Ammonia deposition threatens ecosystem biodiversity, because it contributes to acidification and eutrophication processes (Petersen et al., 1998; Wagner et al., 2017; Truong et al., 2018; Zilio et al., 2020). Furthermore, $\mathrm{NH}_{3}$ can be transformed into nitrous oxide (which contributes significantly to the greenhouse gas effect), or into nitrate (which can leach into ground and surface waters, affecting aquatic biodiversity) (Verdi et al., 2018; EMEP/EEA, 2019). To progressively reduce the atmospheric emissions of five main air pollutants (including $\mathrm{NH}_{3}$ ), the EU has implemented the National Emissions Ceiling (NEC) Directive (European Environmental Agency, 2016). To ensure that NEC emission tar- 
gets will be met, all Member States must implement measures that improve air quality, including a reduction in $\mathrm{NH}_{3}$ emission from agriculture.

The available techniques to reduce agricultural $\mathrm{NH}_{3}$ emissions include inter alia covering manure and slurry storage facilities, cooling storage facilities and/or contents, acidifying slurry, stripping $\mathrm{NH}_{3}$, fractioning fertilization during crop growth, and fertigation using slurry or digestate (Rotz et al., 2014; European Commission, 2017). Fertigation is a valid alternative to other fertilization practices, because it can minimize nitrogen loss, while facilitating the utilization of animal (and crop) wastes, thereby contributing to circularity within a farming system (European Commission, 2017; Finzi et al., 2019; Guido et al., 2020a).

In particular, fertigation is a suitable technique for using the digestate resulting from anaerobic digestion as a crop fertilizer. To be used in this way, the digestate is usually first processed through a screw-press separator to produce a liquid fraction that is rich in nitrogen. The separated digestate is an excellent fertilizer, because the retained nitrogen is in ammoniacal form, which is readily used by plants (Guilayn et al., 2019). However, for the same reason, the potential for $\mathrm{NH}_{3}$ emissions to occur from digestate is high (Guido et al., 2020a). To minimize these emissions, care and attention must be exerted when utilizing this product. The preferred application technique is by direct incorporation into the soil (Riva et al., 2016; Verdi et al., 2018). However, this approach limits the application of digestate to pre-sowing periods, which in turn reduces the nitrogen utilization efficiency; because nitrogen is applied long before crops will be able to uptake it, causing nitrogen leaching into the soil.

Fertigation using digestate via drip irrigation or sprinkler irrigation (such as driplines or pivot systems) can be a suitable technique to overcome these problems. Fertigation allows the total dose of nitrogen to be fractionated throughout the growing season, thereby limiting nitrogen emissions both in the soil and in the air (Hanson et al., 2006; Guido et al., 2020a). However, when the liquid fraction of digestate is used in fertigation, additional filtration (after a screw press) is required to remove solids that are larger than the nozzle holes in the irrigation system. Typically, advanced filtration is achieved using mechanical separation equipment such as vibrating screens or micro-filters that have screen openings of 50-500 microns (Guilayn et al., 2019; Guido et al., 2020a).

Using digestate in fertigation within a farm also enhances the circularity of resource use. However, compared to simply injecting digestate into the soil, the additional filtration step that enables digestate to be used in a fertigation system may contribute to additional $\mathrm{NH}_{3}$ emissions into the atmosphere.

The EU's 'Reference Document on Best Available Techniques' for intensive livestock facilities states that the storage, manipulation and spreading of organic fertilizers all contribute to $\mathrm{NH}_{3}$ emissions, and it is therefore important to evaluate the contribution of each process (European Commission, 2017). Some studies have already assessed the impact of some processes, such as digestate storage or digestate spreading; however, little research has been conducted on the digestate separation process. The advanced filtration step required for fertigation using digestate has not yet been investigated (Wolf et al., 2014; Bell et al., 2016; Riva et al., 2016; Finzi et al., 2019). Since digestate filtration involves digestate movement in semi-open environments, it is important to evaluate potential emissions that may occur. Only then a complete description can be developed of the overall environmental impact and the impact of each element in the digestate management/fertigation system. To monitor $\mathrm{NH}_{3}$ emissions coming from the advanced filtration of digestate being used for fertigation, this study examined three farms located in the Lombardy region of Italy. Lombardy was chosen as the study site because this region is the most active in terms of both livestock and biogas production, and its agricultural activities contribute $94 \%$ of total $\mathrm{NH}_{3}$ emissions in Italy (ISPRA, 2019). This region is also more vulnerable to air pollution accumulation due to its geo-pedological characteristics. Therefore, major efforts are required to implement solutions for reducing $\mathrm{NH}_{3}$ emissions in order to protect both human and environmental health (European Commission, 2017; Wagner et al., 2017).

The study aimed to monitor $\mathrm{NH}_{3}$ emissions from filtration of the liquid fraction of digestate before its use for fertigation. The study had the primary objective of assessing the percentage of increase in $\mathrm{NH}_{3}$ emissions coming from the digestate filtration process, compared to when it was inactive. Secondly, the study aimed to evaluate the magnitude of $\mathrm{NH}_{3}$ emissions of the filtration system, having literature values of other emitting elements as reference.

\section{Materials and methods}

\section{Experimental set-up}

This study was part of the EU-sponsored LIFE project 'ARIMEDA' (Ammonia emission reduction in Mediterranean agriculture with innovative slurry fertigation techniques) (LIFE16 ENV/ES/000400). The project monitored $\mathrm{NH}_{3}$ emissions from digestate fertigation systems on different farms in the Po Valley.

The experiments took place in three of these farms that were in different areas of the Po Valley in Lombardy region in Northern Italy: Mantua province, $45^{\circ} 02^{\prime} 56.9^{\prime} \mathrm{N} 10^{\circ} 25^{\prime} 51.6^{\prime} \mathrm{E}$ (farm A); Brescia, $45^{\circ} 26^{\prime} 43^{\prime} \mathrm{N}, 9^{\circ} 57^{\prime} 00^{\prime} \mathrm{E}$ (farm B); and Pavia, $45^{\circ} 13^{\prime}$ $47^{\prime} \mathrm{N} 9^{\circ} 22^{\prime}$ 07' E (farm C).

Each farm had an anaerobic digestion plant (AD), a separation system and an irrigation system whose main characteristics are reported in Table 1 .

Within each farm, a two-stage liquid-solid separation system was specifically designed to prepare liquid digestate suitable for injection into the irrigation system. In the first stage of filtration, digestate passed through a screw-press separator that was already installed on each farm. Then, depending on the type of irrigation system used, the liquid fraction from the screw-press was further filtered using different types of separators with different screen sizes, to prevent clogging of the irrigation system nozzles. In farms A and C, the irrigation system consisted of driplines (Typhoon plusTM, Netafim, Tel Aviv, Israel) and advanced filtration was accomplished using a vibrating screen (farm $\mathrm{C}$ ) or a microfilter (farm A) with small openings. In farm B, the irrigation system consisted of centre pivot with nozzle openings larger than driplines and therefore in this farm the required level of advanced filtration was obtained using a vibrating screen with larger screen size than other farms.

In all farms, the liquid fraction passed through an in-line filter before being injected into the irrigation system. This screen filter with a mesh of $120 \mu \mathrm{m}$ (before the driplines) or $300 \mu \mathrm{m}$ (before the pivot) was an additional safety system to avoid nozzle clogging.

The functioning of the advanced filtration system was monitored by recording digestate flow rates and characteristics.

The evaluation of $\mathrm{NH}_{3}$ emissions was limited to the advanced filtration system, which was monitored during its activity (' $\mathrm{ON}$ ') and when it was switched off (OFF') with the aim to detect the percentage increase in ammonia emissions due to its functioning. All the other components of the overall filtration system were maintained in the same state. Sampling days and durations of emission monitoring were different among farms, depending on farming practices (Table 2). 


\section{Separation system monitoring}

To determine the amount of digestate into each advanced filtration system, the volumes of treated digestate from the screw press were monitored using a counter placed on the inlet of the equipment, while the amount of liquid fraction obtained was measured by a counter on the outlet of the equipment. The duration of the filtration operation was then used to calculate the hourly flow rates. Chemical analyses were performed on collected samples of the digestate liquid fraction to determine total solids (TS), total Kjeldahl nitrogen (TKN), total ammoniacal nitrogen (TAN), total phosphorus (TP), and total potassium (TK). All parameters were analysed using standard methods (APHA/AWWA/WEF, 2012). In this respect, it is worth noting that the filtered digestate had a relatively high TS content (2.9-4.4\%) and a relevant amount of organic nitrogen (Table 3). In fact, the TAN accounted for 53-73\% of the total nitrogen. During anaerobic digestion, some organic nitrogen mineralizes, but the digestate also retains some of the organic nitrogen in small particles that cannot be removed even with the advanced filtration system.

During $\mathrm{NH}_{3}$ monitoring, different amounts of digestate were treated on different farms, with different working times and flow rates (Table 3). Flow rates and total nitrogen parameters are essential data that were used to better understand and compare emission results among farms.

Table 1. Characteristics of the AD plants, separation and irrigation systems for each farm.

\begin{tabular}{|c|c|c|c|c|c|c|c|c|}
\hline \multirow[t]{3}{*}{ Farm } & \multirow{2}{*}{\multicolumn{2}{|c|}{ AD plant }} & \multicolumn{4}{|c|}{ Separation system } & \multicolumn{2}{|c|}{ Irrigation system } \\
\hline & & & First & & Second & age & Type & Nozzles \\
\hline & $\begin{array}{l}\text { Power } \\
\text { (MWe) }\end{array}$ & $\begin{array}{l}\text { Feedstock } \\
\text { composition }\end{array}$ & Equipment & $\begin{array}{l}\text { Screen size } \\
(\mu \mathrm{m})\end{array}$ & Equipment & $\begin{array}{l}\text { Screen size } \\
(\mu \mathrm{m})\end{array}$ & & \\
\hline A & 1 & $\begin{array}{c}50 \% \text { pig/cattle } \\
\text { slurry, } 10 \% \text { poultry } \\
\text { manure, } 40 \% \text { agri- } \\
\text { food by-products }\end{array}$ & Screw-press & 500 & Microfilter & 50 & Dripline & $<200 \mu \mathrm{m}$ \\
\hline B & 1 & $\begin{array}{l}95 \% \text { maize silage, } \\
5 \% \text { by-products }\end{array}$ & Screw-press & 800 & Vibrating screen & 500 & Pivot & $>2 \mathrm{~mm}$ \\
\hline C & 0.3 & $\begin{array}{l}80 \% \text { pig slurry, } 20 \% \\
\text { maize silage }\end{array}$ & Screw-press & 450 & Vibrating screen & 100 & Dripline & $<200 \mu \mathrm{m}$ \\
\hline
\end{tabular}

Table 2. Sampling days, monitoring durations and mean values (standard error in brackets) of weather conditions during ammonia emission evaluation for each farm under study.

\begin{tabular}{|c|c|c|c|c|c|c|}
\hline Farm & Prototype conditions & Sampling days & Duration & Wind speed $(\mathrm{m} / \mathrm{s})$ & $\begin{array}{c}\text { Temperature }\left({ }^{\circ} \mathrm{C}\right) \\
\text { Mean (SE) }\end{array}$ & Pluviometry (mm) \\
\hline \multirow[t]{2}{*}{ A } & $\mathrm{ON}$ & $\begin{array}{l}14,15 \text { and } 22 \text { July } \\
2020\end{array}$ & $76 \mathrm{~h}$ & $1.2(0.11)$ & $22.9(0.59)$ & $0.3(0.17)$ \\
\hline & OFF & 13 and 23 July 2020 & $72 \mathrm{~h}$ & $1.6(0.15)$ & $21.8(0.55)$ & $0.5(0.29)$ \\
\hline \multirow[t]{2}{*}{ B } & ON & $\begin{array}{l}28 \text { July and } 6 \text { August } \\
2020\end{array}$ & $45 \mathrm{~h}$ & $0.6(0.08)$ & $28.2(0.82)$ & $0(0)$ \\
\hline & OFF & $\begin{array}{c}31 \text { July and } 01 \\
\text { August } 2020\end{array}$ & $30 \mathrm{~h}$ & $0.8(0.12)$ & $29.1(1.13)$ & $0(0)$ \\
\hline \multirow[t]{2}{*}{$\mathrm{C}$} & $\mathrm{ON}$ & 12 August 2020 & $10 \mathrm{~h}$ & $0.6(0.06)$ & $32.5(0.63)$ & $0(0)$ \\
\hline & OFF & 14 August 2020 & $10 \mathrm{~h}$ & $0.5(0.05)$ & $32.5(0.47)$ & $0(0)$ \\
\hline
\end{tabular}

Table 3. Flowrate of the advanced filtration system and characteristics of the liquid fraction obtained for each farm (standard error in brackets).

\begin{tabular}{lcccc} 
Parameter & Units & Farm A & $\begin{array}{c}\text { Farm B } \\
\text { Mean (SE) }\end{array}$ & Farm C \\
Flow rate & $\mathrm{m} / \mathrm{h}$ & $2.9(0.20)$ & $7.1(0.57)$ & $5.4(0.47)$ \\
TS & $\%$ & $4.4(0.14)$ & $4.8(0.29)$ & $2.9(0.10)$ \\
\hline TKN & $\mathrm{kg} / \mathrm{m}^{3}$ & $5.1(0.14)$ & $6.1(0.42)$ & $4.5(0.16)$ \\
TAN & $\mathrm{kg} / \mathrm{m}^{3}$ & $3.7(0.03)$ & $4.2(0.09)$ & $2.4(0.03)$ \\
TP & $\mathrm{kg} / \mathrm{m}^{3}$ & $0.5(0.02)$ & $0.9(0.07)$ & $0.4(0.05)$ \\
TK & $\mathrm{kg} / \mathrm{m}^{3}$ & $2.3(0.02)$ & $2.8(0.08)$ & $1.7(0.11)$ \\
\hline
\end{tabular}




\section{Ammonia emission monitoring}

Passive CEH ALPHA ${ }^{\circledR}$ samplers (Adapted Low-cost Passive High Absorption, UK Centre for Ecology \& Hydrology, Gwynedd, UK) were used (Carozzi et al., 2013) to measure $\mathrm{NH}_{3}$ concentrations emitted from the advanced filtration systems. For each sampling, a total of 32 passive samplers were placed on masts located at the four corners of the platform on which the filtration system was mounted. The samplers were placed beneath a plastic holder to shield them from rain and dew. On each mast, four samplers were positioned at each of two heights: $0.70 \mathrm{~m}$ above the base of the mounting platform (designated 'low') and at $2.2 \mathrm{~m}$ above the platform (designated 'high') (Figures 1 and 2).

The two sampling heights were selected to allow detection of variations in ammonia concentrations in the emission plume as a function of height above the emitting source. The 'low' height corresponded to the height of the advanced filter surface, while the 'high' height was set at $1.5 \mathrm{~m}$ above the filter surface. These positions were selected based on previous research that measured $\mathrm{NH}_{3}$ emissions both from storage facilities and fields (Carozzi et al., 2013; Bell et al., 2016; Ferrara et al., 2016).

Filters in the passive samplers were first soaked in $50 \mu \mathrm{l}$ of a coating solution $13 \%(\mathrm{~m} / \mathrm{v})$ of citric acid and methanol to enable ammonia capture. Samplers were placed on masts to monitor $\mathrm{NH}_{3}$ emissions coming from the advanced filter when functioning $(\mathrm{ON})$ and when idle (OFF). At the end of each monitoring period, samplers were removed, sealed to prevent further ammonia capture, and stored at $4{ }^{\circ} \mathrm{C}$ until further analysis (Stephens and Poskitt, 2017).

To measure the captured ammonia concentrations, filters were removed from the samplers, diluted in $3 \mathrm{~mL}$ of deionized water, and then analysed in a flow injection analysis system (Fiastar 5000 Analyser, Foss, Hilleroed, Denmark) using the $4500-\mathrm{NH} 3 \mathrm{H}$ method (APHA/AWWA/WEF, 2012).

Weather conditions were monitored in each farm. To detect wind speed and wind direction, an anemometer (model DW-6410, Davis Instruments Corporation, Hayward, CA, USA) was installed on the platform of the filtration system at a height of $1.1 \mathrm{~m}$. Data were recorded with a frequency of 15 minutes. To measure temperature, in farm A and B data were recorded every 15 minutes by a meteor station (Vantage pro2, Davis Instruments Corporation, Hayward, CA, USA) located in the same environment of the filtration system. In farm $\mathrm{C}$, temperature was obtained by the ARPA network, located in the station of Landriano - Pavia (13 km far from

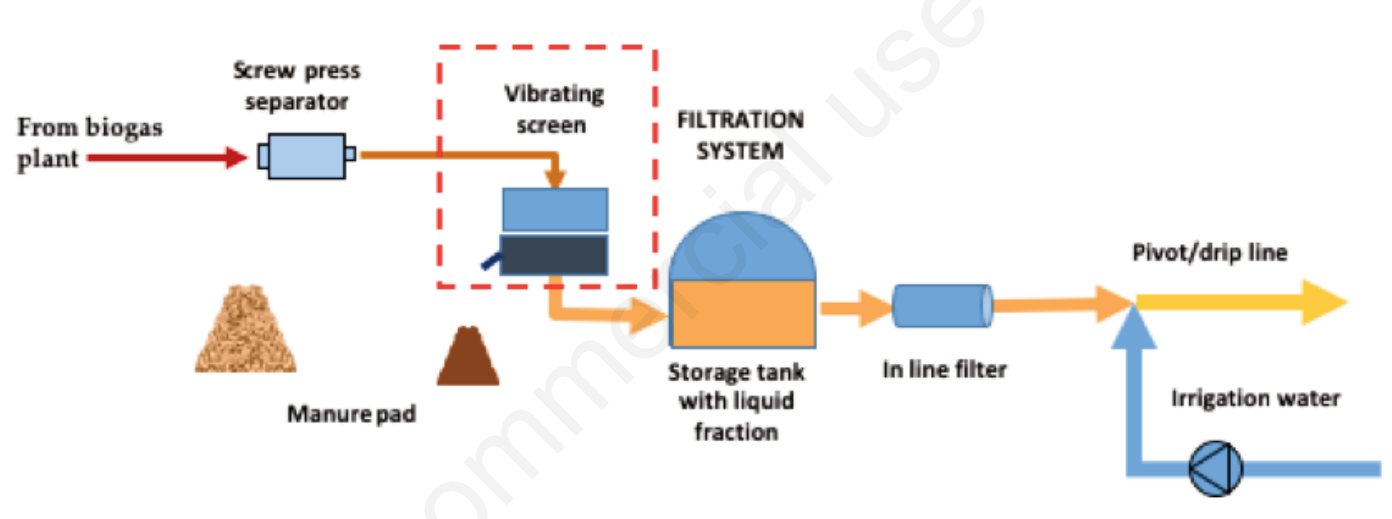

Figure 1. Schematic representation of the separation process in all its steps. The area highlighted within the red box defines the area of interest for the ammonia emission monitoring.

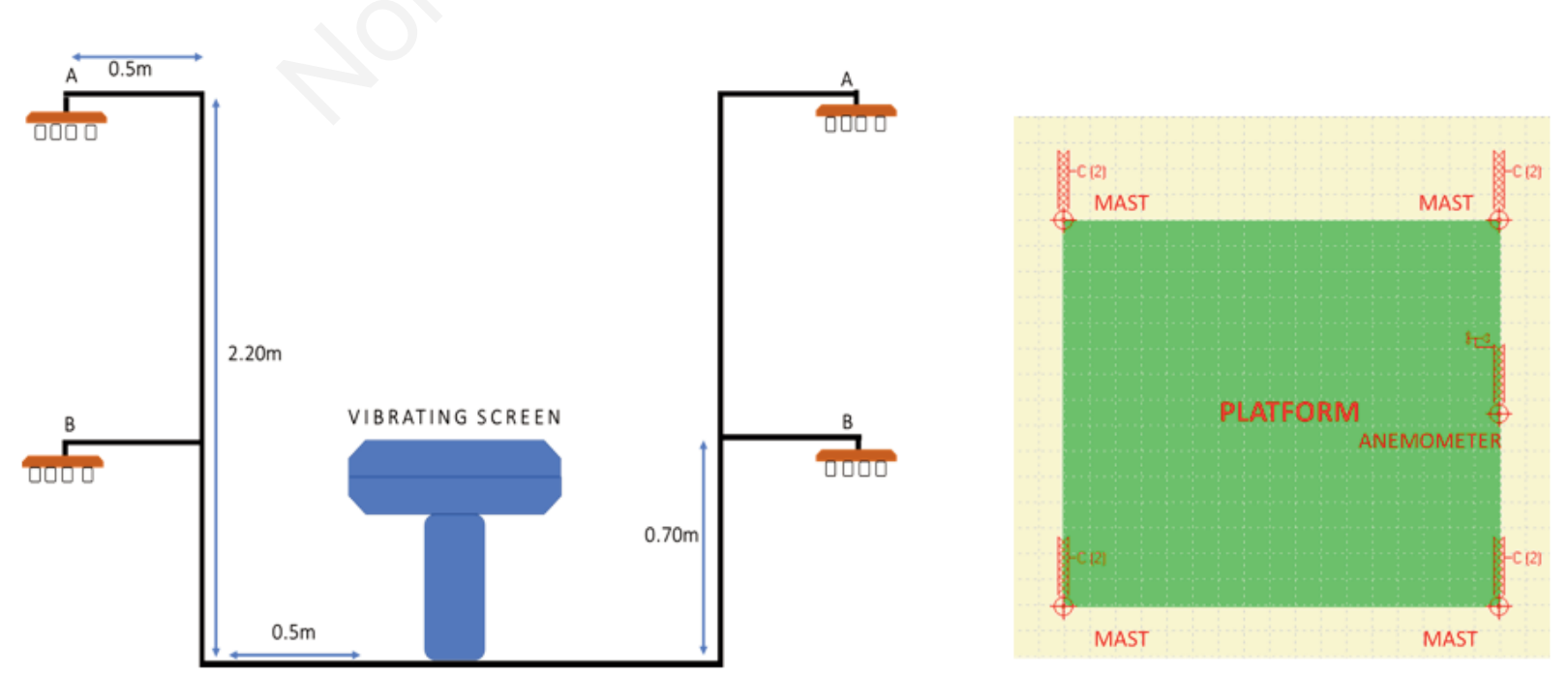

Figure 2. Left: Scheme of the emission monitoring system for the advanced filter. Right: Representation of the sampling scheme for the Windtrax model, the green area represents the emitting source. 
the farm), which recorded data every 60 minutes (ARPAL, 2020).

\section{Ammonia emissions rates}

Windtrax 2.0 software (Thunder Beach Scientific, Halifax, Canada) was used to quantify ammonia emission rates. This software is based on the backward Lagrangian stochastic model, a micrometeorological method of inverse dispersion modelling (Carozzi et al., 2013; Scotto Di Perta et al., 2020). The model estimates $\mathrm{NH}_{3}$ emissions using $\mathrm{NH}_{3}$ concentrations measured downwind from the source (Flesch et al., 2004). Measured data for hourly wind speed, wind direction and air temperature were entered as principal inputs in the model.

To run the simulation, a separate Windtrax project was designed for each farm, where the filtration system was represented as a squared emitting surface with the dimensions of the platform where those systems were mounted. Within each project, masts were placed on the platform to reflect the experimental setup. Before running the simulations, some values were setup as follows: i) number of particles: 50,000; ii) stability: L MoninObukhov length $=$ Infinite $\mathrm{m}$; iii) surface roughness $\mathrm{Z} 0=1 \mathrm{~cm}$.

Simulations were run for each farm by using an input file with hourly data of wind speed, wind direction, temperature and $\mathrm{NH}_{3}$ concentration of the 8 sampling points.

\section{Statistical analysis}

A statistical analysis of the experiment results was performed using IBM ${ }^{\circledR}$ SPSS ${ }^{\circledR} 26$ software (IBM Corp., Armonk, NY, USA). The first objective of this analysis was to compare $\mathrm{NH}_{3}$ emissions coming from the two operating conditions of the advanced filter within each farm (separately for ON and OFF periods), to check for significant differences in emissions when the filters were active and when they were idle. Before emissions were compared, a preliminary statistical analysis was performed to check homogeneity of weather conditions between monitoring periods. If weather conditions were not homogeneous, a cluster analysis was performed to identify sub-groups of data that shared the same meteorological conditions, thus enabling a reliable comparison of emissions. Ammonia emission rates were then compared by performing an analysis of variance with homogeneity tests (Univariate and Levene tests). If variances were not homogeneous among the monitoring conditions, a non-parametric test for independent samples was performed (Independent-Samples Mann-Whitney U Test).

\section{Effect of the filtration process in the slurry injection process}

To identify whether the advanced filtration process had an actual impact on $\mathrm{NH}_{3}$ emissions, it was important to contextualize the results within the whole system surrounding the filter. Indeed, the separation process was only one of many emitting elements that comprised the system.

However, the assessment of emissions from the whole fertigation system was outside the scope of the study. Therefore, the evaluation was limited to the impact of the emissions on the nutrient content of the managed digestate.

For this purpose, each farm was evaluated by extending the measured emissions to the whole fertigation season. Because the monitored filtration systems were used to fertigate maize, the irrigation season was 100 days. Furthermore, the filtration system was considered to be working for 400 hours per season, as reported by Guido et al. (2020a).

The processed digestate and its nitrogen content were based on the values reported in Table 2 .

\section{Results and discussion}

\section{Weather}

In farm $\mathrm{A}$, the means and variances of temperature and wind speed were different in the ON and OFF periods. Therefore, a cluster analysis was performed, from which three sub-groups of weather clusters were identified: cluster 1: wind speed $=0.64 \mathrm{~m} / \mathrm{s}$ and temperature $=18.60^{\circ} \mathrm{C}$; cluster 2 : wind speed $=1.33 \mathrm{~m} / \mathrm{s}$ and temperature $=27.94^{\circ} \mathrm{C}$; cluster 3 : high wind speed $=2.98 \mathrm{~m} / \mathrm{s}$ and medium temperature $=22.9^{\circ} \mathrm{C}$. Ammonia emission rates were compared
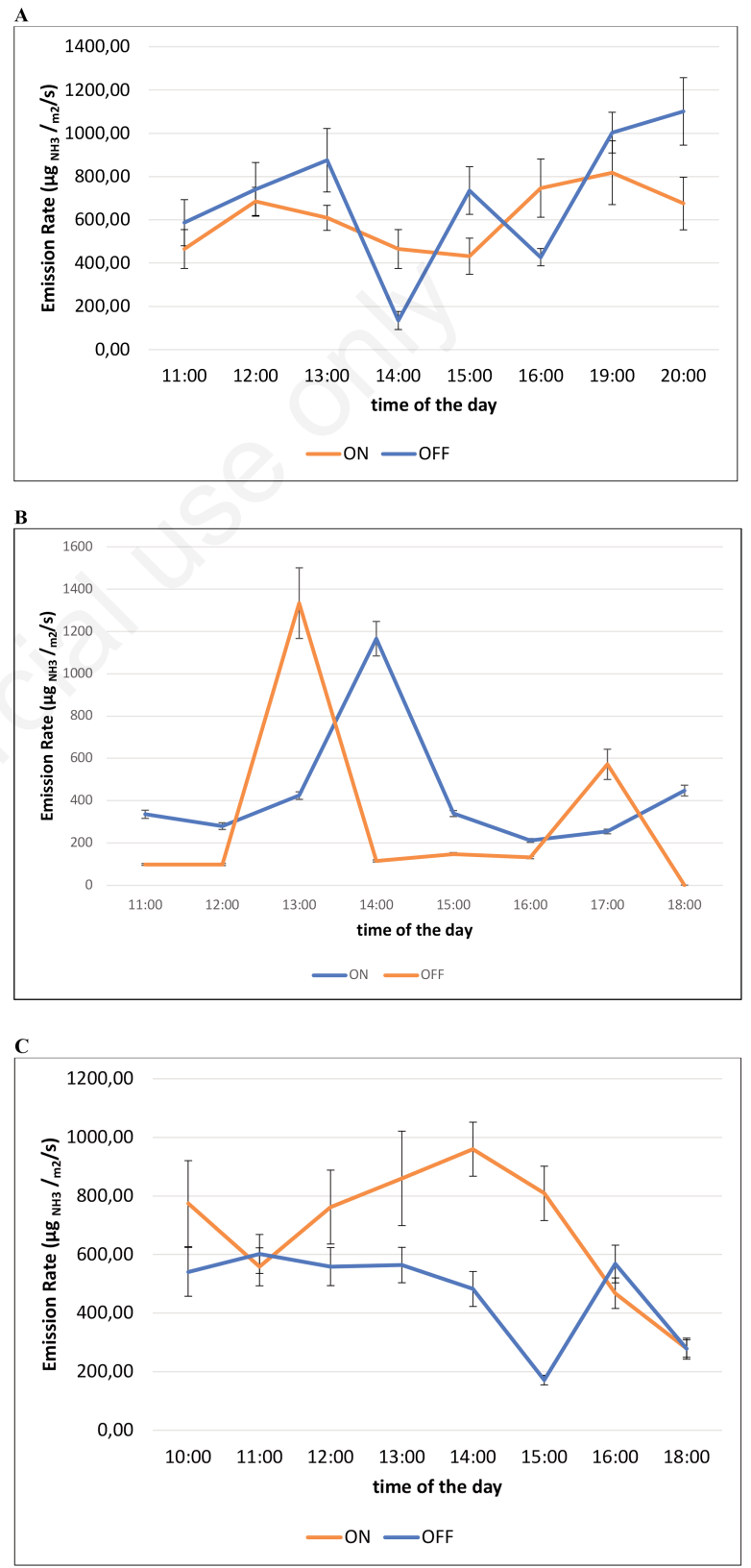

Figure 3. Examples of hourly $\mathrm{NH}_{3}$ emissions from the advanced filtration systems during $\mathrm{ON}$ and OFF periods on farm $\mathrm{A}$ ), B) and $C$ ) displayed in this cited order. For farm $A$ the $O N$ period was $15 / 07 / 2020$ and the OFF period was $23 / 07 / 2020$. For farm $B$ the ON period was $28 / 07 / 20$ and the OFF period was $01 / 08 / 20$. For farm $C$ the $O N$ period was $12 / 08 / 2020$ and the OFF period was 14/08/2020. 
within each cluster. In farms $\mathrm{B}$ and $\mathrm{C}$, although weather conditions varied throughout the experiments, the variances of temperature and wind speed during the two conditions (ON and OFF) were homogeneous. Therefore, the comparison of $\mathrm{NH}_{3}$ emission rates was conducted using the whole data set.

\section{Ammonia emissions rates}

The hourly $\mathrm{NH}_{3}$ emissions estimated by the Windtrax software were analysed and compared. Figure 3 reports an example of the hourly variations in $\mathrm{NH}_{3}$ emissions on two of the farms for the $\mathrm{ON}$ and OFF conditions of the filtration system. There was noticeable variability in the emissions due to the changing weather conditions, especially wind speed and direction. Nevertheless, emissions during the two conditions were not statistically different.

The statistical analysis showed that $\mathrm{NH}_{3}$ emissions from the advanced filters on all three farms tended to increase the ammonia in the atmosphere, but with no significant difference in emission rates between $\mathrm{ON}$ and OFF periods (Figure 4). Although the changes in temperature and wind speed caused some variability in emissions during the day, the mean emission rates during $\mathrm{ON}$ and OFF periods on each farm were similar. In farm A, the highest $\mathrm{NH}_{3}$ emission rate from a filtration system $\left(1841 \mu \mathrm{g} \mathrm{NH} / \mathrm{N}_{3}^{2} / \mathrm{s}\right)$ occurred during the $\mathrm{ON}$ period. The lowest $\mathrm{NH}_{3}$ emission rate $(270$ $\mu \mathrm{g} \mathrm{NH} / \mathrm{m}^{2} / \mathrm{s}$ ) was measured in farm B when the filtration system was OFF. Emission rates obtained from the three farms cannot be directly compared, as their system setup and characteristics were not similar, however their magnitude was the same. The mean $\mathrm{NH}_{3}$ emission rates in the three farms were 876, 375 and $569 \mu \mathrm{g}$ $\mathrm{NH}_{3} / \mathrm{m}^{2} / \mathrm{s}$ for farms $\mathrm{A}, \mathrm{B}$ and $\mathrm{C}$, respectively. The higher values in farm A can be explained by the different weather conditions of the experiments (Table 2).

Although not statistically significant, the tendency for $\mathrm{NH}_{3}$ emissions to increase, when the filtration system was operating, was quite clear and in line with expectations. In fact, the movement of digestate on the screen can enhance the release of $\mathrm{NH}_{3}$ during this operation.

Compared to the mean $\mathrm{NH}_{3}$ emission during the OFF periods, the emissions increased by $23 \%, 77 \%$ and $42 \%$ during the ON period on farms A, B and C, respectively. The percentage in farm $A$ is the mean of the values of the three clusters. The higher increase in farm B was coherent with the different characteristics of its filtration system (see Table 2: wider screen size and consequently a higher flowrate, in comparison to farm A and C).

There are few references that quantify $\mathrm{NH}_{3}$ emissions from digestate separation systems, although it is known that they occur during this process (European Commission, 2017). In contrast, numerous references exist about $\mathrm{NH}_{3}$ emissions during storage. For example, Kupper et al. (2020) reviewed this topic and found that the baseline $\mathrm{NH}_{3}$ emissions are $22-67 \mu \mathrm{g} \mathrm{NH} / 3 \mathrm{~m}^{2} / \mathrm{s}$ for cattle and pig slurry stored in tanks.

On the basis of the reference values for storage, it is possible to consider that the resulting $\mathrm{NH}_{3}$ emissions from the filtration sys- tem of our study are one order of magnitude lower. This difference was expected because the movement of the digestate during the filtration process causes turbulence and mixing, which in turn enhances $\mathrm{NH}_{3}$ emissions. The $\mathrm{NH}_{3}$ emissions when the filtration systems were OFF were also relatively high. Emissions during the OFF periods might be related to the wetted area of the filter and the storage of the separated fractions, both of which continue to emit $\mathrm{NH}_{3}$ even when the equipment is not operating. Therefore, in order to evaluate the possible contribution of the advanced filtration system to the whole process of digestate management for fertigation, average values of emissions during both the ON and OFF periods must be considered.

\section{Impact of the filtration process on nitrogen losses}

The data reported in Table 4 show that the nitrogen lost as $\mathrm{NH}_{3}$ during the advanced filtration process was limited. Although the variability in emissions was high, an average value of $0.3 \%$ of the nitrogen contained in the filtered digestate was lost through $\mathrm{NH}_{3}$ emissions during advanced filtration. $0.3 \%$ is the mean percentage of the three farms, and represents the fraction of nitrogen emitted by the filtration process, compared to the nitrogen contained in the flow incoming into the filtration system before processing.

On first examination, the low mass loss is surprising given that the specific $\mathrm{NH}_{3}$ emissions per square meter were one order of magnitude higher than those for storage tanks. However, it has to be considered that, while uncovered storage tanks have a large emitting surface, the emission area of an advanced filtration system is just a few square meters. A storage tank for $2000 \mathrm{~m}^{3}$ of digestate with a useful height of $4 \mathrm{~m}$ has a surface area of $500 \mathrm{~m}^{2}$ compared to the maximum area of $12 \mathrm{~m}^{2}$ for the advanced filtration equipment.

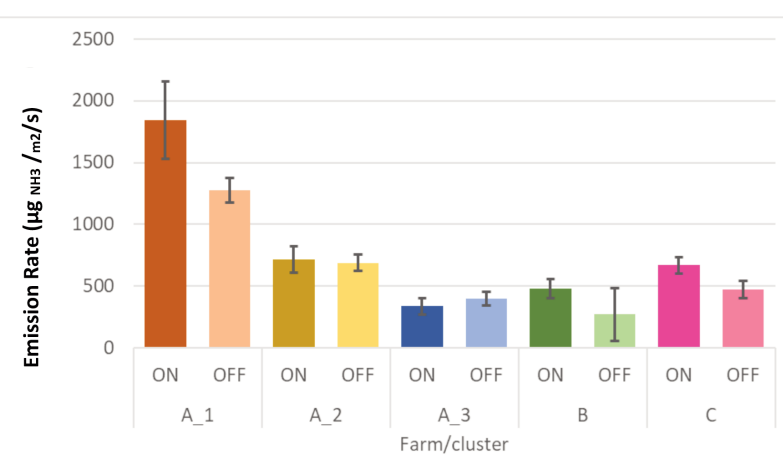

Figure 4. Mean ammonia emissions from advanced filtration of digestate on farms $\mathrm{A}, \mathrm{B}$ and $\mathrm{C}$ when the filter was $\mathrm{ON}$ and $\mathrm{OFF}$. $\mathrm{A} 1, \mathrm{~A} 2$ and $\mathrm{A} 3$ are clusters of time when climatic conditions were homogeneous on farm A. Error bars represent the standard error.

Table 4. Impact of the advanced filtration system on the mass nitrogen losses from the processed digestate in farms A, B and C (standard error in brackets).

\begin{tabular}{|c|c|c|c|c|c|}
\hline Parameter & Units & Farm A & Farm B & Farm C & Average \\
\hline Average emissions, mean (SE) & $\mu \mathrm{g} \mathrm{NH} 3 / \mathrm{m}^{2} / \mathrm{s}$ & $876(118)$ & $375(146)$ & $569(66)$ & 607 \\
\hline Emitting area & $m^{2}$ & 4 & 12 & 6.3 & 7.4 \\
\hline Emissions during the season & $\mathrm{kg} \mathrm{NH} 3$ & 30.3 & 38.9 & 30.7 & 38.9 \\
\hline Volume of digestate processed & $\mathrm{m}^{3}$ & 1,160 & 2,840 & 2,160 & 2,053 \\
\hline Nitrogen processed & $\mathrm{kg}$ & 5,916 & 17,324 & 9,720 & 10,746 \\
\hline Nitrogen emitted/processed & $\%$ & $0.42 \%$ & $0.18 \%$ & $0.26 \%$ & $0.30 \%$ \\
\hline
\end{tabular}


Previous research has shown that storage of separated liquid digestate emits almost four times more $\mathrm{NH}_{3}$ than raw digestate (Balsari et al., 2013). Therefore, even though the advanced separation process might not directly contribute significantly to $\mathrm{NH}_{3}$ emissions, the separated fractions, when stored, greatly influence emissions. Of course, this problem also depends on the type of storage. Another study found that the majority of AD plants store the liquid fraction of digestate in uncovered tanks (Gioelli et al., 2011). An uncovered storage tank for digestate typically emits (as $\left.\mathrm{NH}_{3}\right) 21 \%$ of the total nitrogen contained in the digestate, while these losses are reduced to $4 \%$ and $2 \%$ from a storage tank that is covered with natural crust (or straw) and with a tent (or concrete), respectively (European Commission, 2017). Thus, only when covered digestate storage tanks are used in the overall fertigation system will the $\mathrm{NH}_{3}$ emissions from an advanced filtering system be a noticeable (albeit small) component of the total nitrogen emissions. Further ammonia emissions also occur during field application of digestate. These emissions can vary greatly depending on the technique used. Considering a broadcast spreader, the expected losses are around $47-60 \%$ of initial TAN content, which are reduced to $20-25 \%$ by using the closed-slot injection and to $3-4 \%$ considering the integration with mitigating interventions during storage, such as acidification (Finzi et al., 2019). Furthermore, even the use of a digestate management system based on the fertigation technique makes it possible to reduce ammonia emissions by around $65 \%$ (Guido et al., 2020b), but the emission flows are still higher than those found in this study during the separation with vibrating screens.

\section{Conclusions}

Digestate separation and subsequent filtration are fundamental processes for producing a liquid digestate fraction that is suitable for injection into a fertigation system. Fertigation allows for the enhanced use of digestate and helps to limit $\mathrm{NH}_{3}$ emissions at field level. Fertigation makes it possible to fraction the total crop need for nitrogen, which minimizes $\mathrm{NH}_{3}$ loss into the atmosphere and maximizes nitrogen utilization efficiency. However, the storage, manipulation, and processing of digestate contribute to $\mathrm{NH}_{3}$ emissions. This study examined $\mathrm{NH}_{3}$ emitted from the specific process of advanced digestate filtration. Advanced filtration does influence $\mathrm{NH}_{3}$ emissions, but the magnitude of emissions from advanced filtration during operation are not significantly different from those that occur when the equipment is idle. Furthermore, the combined $\mathrm{NH}_{3}$ emissions from advanced filtration in operation and in idle periods are not relevant in terms of mass nitrogen loss and are on average only approximately $0.3 \%$ of the total nitrogen contained in the digestate.

This research work provides a first insight into the $\mathrm{NH}_{3}$ emissions that arise from advanced filtration of digestate, with specific reference to farming systems in the Po Valley (Italy). However, the study was conducted only over a relatively short time, and only three farms were examined.

Therefore, in order to obtain more generally applicable information on ammonia emissions from filtration systems, these findings should be supported with further research to collect data in different conditions and obtain a better description of the dynamics that influence $\mathrm{NH}_{3}$ emissions during the filtration process. This will allow to obtain emission factors that could be used in inventories and Life Cycle Inventories to provide a better understanding of which steps of the process should be improved to lower emissions. Furthermore, $\mathrm{NH}_{3}$ emissions from all the emitting sources in the farming system under study should be measured simultaneously with those from the advanced filtration system to obtain a detailed assessment of the contribution of each element to $\mathrm{NH} 3$ emissions from the whole system.

\section{References}

Aneja V.P., Chauhan J.P., Walker J.T. 2000. Characterization of atmospheric ammonia emissions from swine waste storage and treatment lagoons. J. Geophys. Res. 105:11535-45.

APHA/AWWA/WEF, 2012. Standard methods for the examination of water and wastewater. Stand. Methods: 541.

Balsari P., Dinuccio E., Gioelli F. 2013. A floating coverage system for digestate liquid fraction storage. Bioresour. Technol. 134:285-9.

Bell M.W., Tang Y.S., Dragosits U., Flechard C.R., Ward P., Braban C.F. 2016. Ammonia emissions from an anaerobic digestion plant estimated using atmospheric measurements and dispersion modelling. Waste Manag. 56:113-24.

Carozzi M., Ferrara R.M., Rana G., Acutis M. 2013. Evaluation of mitigation strategies to reduce ammonia losses from slurry fertilisation on arable lands. Sci. Total Environ. 449:126-33.

EMEP/EEA, 2019. Air pollutant emission inventory guidebook 2019. Technical guidance to prepare national emission inventories. Appendix 3.D. Crop production and agricultural soils, pp. 1-38. Available from: https://www.eea.europa.eu/publications/emep-eea-guidebook-2019/part-b-sectoral-guidancechapters/4-agriculture

European Commission, 2017. Best Available Techniques (BAT) Reference Document for the Intensive Rearing of Poultry or Pigs. Inst. Prospect. Technol. Stud. Eur. IPPC Bur.:855. Available from: http://eippcb.jrc.ec.europa.eu/ reference/BREF/IRPP_Final_Draft_082015_bw.pdf

EUROSTAT, 2017. Agri-environmental indicator - greenhouse gas emissions, pp. 1-12. Available from: https://ec.europa.eu/eurostat/statistics-explained/index.php?title=Archive:Agri-environmental_indicator_-_greenhouse_gas_emissions

Ferrara R.M., Carozzi M., Di Tommasi P., Nelson D.D., Fratini G., Bertolini T., Magliulo V., Acutis M., Rana G. 2016. Dynamics of ammonia volatilisation measured by eddy covariance during slurry spreading in north Italy. Agric. Ecosyst. Environ. 219:1-13.

Finzi A., Riva E., Bicoku A., Guido V., Shallari S., Provolo G. 2019. Comparison of techniques for ammonia emission mitigation during storage of livestock manure and assessment of their effect in the management chain. J. Agric. Eng. 50.

Flesch T.K., Wilson J.D., Harper L.A., Crenna B.P., Sharpe R.R. 2004. Deducing ground-to-air emissions from observed trace gas concentrations: A field trial. J. Appl. Meteorol. 43:487-502.

Gioelli F., Dinuccio E., Balsari P. 2011. Residual biogas potential from the storage tanks of non-separated digestate and digested liquid fraction. Bioresour. Technol. 102:10248-51.

Guido V, Finzi A, Ferrari O, Riva E, Quílez D, Herrero E, Provolo G, 2020a. Fertigation of maize with digestate using drip irrigation and pivot systems. Agronomy. 10 [Epub ahead of print].

Guido V., Finzi A., Piazzi P., Ferrari O., Righi Ricco C., Riva E., Provolo G. 2020b. Effect of mitigation techniques on ammonia emissions and nutrients recovery: the role of fertigation with digestate. '2020 IEEE International Workshop on Metrology for Agriculture and Forestry (MetroAgriFor)', pp. 39-43.

Guilayn F., Jimenez J., Rouez M., Crest M., Patureau D. 2019. Digestate mechanical separation: Efficiency profiles based on anaerobic digestion feedstock and equipment choice. Bioresour. Technol. 274:180-9.

Hanson B.R., Šimůnek J., Hopmans J.W. 2006. Evaluation of urea- 
ammonium-nitrate fertigation with drip irrigation using numerical modeling. Agric. Water Manag. 86:102-13.

Hill R.A., Smith K., Russell K., Misselbrook T., Brookman S. 2008. Emissions of ammonia from weeping wall stores and earth-banked lagoons determined using passive sampling and atmospheric dispersion modelling. J. Atmos. Chem. 59:83-98.

Kupper T., Häni C., Neftel A., Kincaid C., Bühler M., Amon B., VanderZaag A. 2020. Ammonia and greenhouse gas emissions from slurry storage - A review. Agric. Ecosyst. Environ. 300 [Epub ahead of print].

Pacholski A. 2016. Calibrated passive sampling - Multi-plot field measurements of $\mathrm{NH} 3$ emissions with a combination of dynamic tube method and passive samplers. J. Vis. Exp. 2016:1-15.

Petersen S.O., Lind A.M., Sommer S.G. 1998. Nitrogen and organic matter losses during storage of cattle and pig manure. J. Agric. Sci. 130:69-79.

Phillips V.R., Lee D.S., Scholtens R., Garland J.A., Sneath R.W. 2001. A review of methods for measuring emission rates of ammonia from livestock buildings and slurry or manure stores, part 2: Monitoring flux rates, concentrations and airflow rates. J. Agric. Eng. Res. 78:1-14.

Rabaud N.E., James T.A., Ashbaugh L.L., Flocchini R.G. 2001. A passive sampler for the determination of airborne ammonia concentrations near large-scale animal facilities. Environ. Sci. Technol. 35:1190-6.

Riva C., Orzi V., Carozzi M., Acutis M., Boccasile G., Lonati S., Tambone F., D'Imporzano G., Adani F. 2016. Short-term experiments in using digestate products as substitutes for mineral $(\mathrm{N})$ fertilizer: Agronomic performance, odours, and ammonia emission impacts. Sci. Total Environ. 547:206-14.

Rotz C.A., Montes F., Hafner S.D., Heber A.J., Grant R.H. 2014. Ammonia emission model for whole farm evaluation of dairy production systems. J. Environ. Qual. 43:1143-58.

Scotto Di Perta E., Fiorentino N., Carozzi M., Cervelli E., Pindozzi S. 2020. A review of chamber and micrometeorological methods to quantify NH3 emissions from fertilisers field application. Int. J. Agron. 2020 [Epub ahead of print].

Truong A.H., Kim M.T., Nguyen T.T., Nguyen N.T., Nguyen Q.T. 2018. Methane, nitrous oxide and ammonia emissions from livestock farming in the Red River Delta, Vietnam: An inventory and projection for 2000-2030. Sustain. 10.

Verdi L., Mancini M., Ljubojevic M., Orlandini S., Marta A.D. 2018. Greenhouse gas and ammonia emissions from soil: The effect of organic matter and fertilisation method. Ital. J. Agron. 13:260-6.

Wagner S., Angenendt E., Beletskaya O., Zeddies J. 2017. Assessing ammonia emission abatement measures in agriculture: Farmers' costs and society's benefits - A case study for Lower Saxony, Germany. Agric. Syst. 157:70-80.

Wolf U., Fuß R., Höppner F., Flessa H. 2014. Contribution of N2O and $\mathrm{NH} 3$ to total greenhouse gas emission from fertilization: Results from a sandy soil fertilized with nitrate and biogas digestate with and without nitrification inhibitor. Nutr. Cycl. Agroecosystems 100:121-34.

Zilio M., Orzi V., Chiodini M.E., Riva C., Acutis M., Boccasile G., Adani F. 2020. Evaluation of ammonia and odour emissions from animal slurry and digestate storage in the Po Valley (Italy). Waste Manag. 103:296-304. 